\title{
Teachers' Implicit Theories on Child Participation in Preschool
}

\author{
By Nada Turnšek ${ }^{*}$
}

\begin{abstract}
With the new paradigm of the sociology of childhood the traditional notion of childhood as a developmental phenomenon has been replaced by the recognition of childhood as an integral part of society and culture rather than simply an antecedent, and by the need for children to be regarded as significant contributors to our society and culture. The concept of "the competent child" and the related concept of child participation poses theoretical as well as practical dilemmas. The paper presents the results of a quantitative study involving 810 respondents, examining Slovenian preschool teachers' views on the implementation of the idea of the competent child and child participation in preschools. Descriptive statistics have been carried out, along with a cluster analysis using Ward's method. The findings suggest the existence of two clusters of beliefs, representing the division between the teachers who support the traditional notion of childhood as a state of immaturity and lack of competence, and those supporting the postmodern concept of the competent child. The first is associated with the concept of participation through a mediator and the latter with the concept of autonomous participation.
\end{abstract}

Keywords: child participation, competent child, implicit theories preschool teachers

\section{The New Sociology of Childhood}

As the study of the history of childhood shows, children were not identified as a group with their own rights but rather as a part of the family and community (Kirby et al., 2003). Parents and teachers decided what was good for them, spoke on their behalf and interpreted their needs. Important changes were brought by the age of Enlightenment with the understanding of the child as a being with a specific way of learning, developing and acting. The ideas of Komenski, Rousseau, and later in the field of preschool education the ideas of Pestalozzi, Owen, Froebl, and Montessori introduce a respectful relation towards the child, their development and learning (Rutar, 2013).

The 20th century with its reform pedagogy indicates a turning point, particularly with Dewey pointing out the role of the child's experience and the child's active role in the processes of learning and participating in democratic processes (Dewey, 1938). At the end of the 1980s, "the new sociology of

\footnotetext{
*Assistant Professor, University of Ljubljana, Slovenia.
} 
childhood" (James \& Prout, 1997) made a shift away from the dominant developmental-psychological paradigm, particularly by breaking away from the linear understanding of the child's development that equates childhood with inability. It stresses that childhood is neither a natural nor a biological feature; instead, it occurs as a specific structural and cultural component of societies. This new understanding of childhood points out that children are part of society and culture and that childhood is not only some "pre-social" stage. Childhood and children are no longer recognised as passive, incompetent and incomplete. They are recognised as social actors here and now, rather than "only" becoming such (James \& Prout, 1997). However, even the $20^{\text {th }}$ century did not essentially contribute to hearing the child's voice in society and education, in their placement as competent social actors. As claimed by Lansdown (2000), children remain socially and politically excluded from the processes of social decision-making and hence they are still not recognised as citizens.

\section{From the Discourse on the Child's Needs to the Discourse on the Child's Rights}

The modern conceptualisation of childhood has established the child as a being of needs; and later in postmodernist thought the discourse on needs became replaced by the discourse on rights; it is argued that it is through the discourse of needs that the child's incapacity is strengthened (Rutar, 2013). The postmodernist perspective of children's rights moves away from the paternalist, protective construction of childhood which emphasises the child as powerless, dependent, vulnerable and in need of protection (Woodhead, 1997), as well as separated from the society of adults and excluded from participating in the creation of their own destiny. Malaguzzi (1993) suggests changing the discourse on the child's needs with a discourse he calls the "rich child", with the image of a child who is rich in their potential, strong, competent and above all connected with adults and other children. Postmodernist thought thus establishes the conceptualisation of the child as a competent being who shapes his/her own meanings and can actively influence the world. In the 1990s, sociologists of childhood focused their attention on children as social actors who co-shape the social reality; they emphasised that childhood is socially constructed, and studies of childhood should deal with research into the reconstruction of childhood in society (James \& Prout, 1997).

\section{The Child as a Competent Learner}

The child's participation in learning processes is grounded in the pedagogical concept of developmentally appropriate practice (Bredekamp \& Rosegrant, 1993), which attributes equal importance to the curriculum as to children's initiatives in the process of their learning. However, as Rutar (2013) points out, the developmentally appropriate practice introduces discourse with the child in mind, which is why it remains the discourse of participation through a mediator. Although education with the child in mind (their 
developmental characteristics, temperament, learning styles, family culture, interests, etc.) often promotes the children's active participation in meaningful learning (e.g. introducing themes and activities that are interesting to them), it does not involve the children's direct contribution (the child expressing their views, proposals, and the inclusion of such proposals in decisions) in the upbringing process itself (Rutar, 2013).

The developmentally appropriate practice establishes the requirement for an encouraging interaction of the preschool teacher with the child, which represents a key starting point for children's self-expression as an initial foundation of participation. Undoubtedly, as mentioned by Bredekamp (1996), children in interactional situations feel accepted and respected, which is a basic lever for a dialogical situation; self-expression and inclusion presume the exchange of initiatives included in the dialogical situation. However, Rutar (2013) points out that we can speak about participation as co-involvement in expression and decision-making only when the child enters social interaction with their own initiatives, proposals with other/s and is co-involved in decision-making about things which are part of their lives; in the planning, realisation, reflection and evaluation of their learning process, their life in their environment. The wording "encouraging interaction" comprises respectfulness in relation to the child, the opportunity for communication, the encouragement of children to express themselves; however, the discourse still includes mainly the reflection about the actions of the teacher, rather than of the reciprocity of the relationship, interaction and dialogic nature (ibid.).

\section{The Pedagogy of Listening - Upbringing as Dialog}

The concept of child participation is for many authors closely related with hearing the child's voice and, in turn, this is linked to the culture of listening. This points to the tendency of viewing the child as capable of expressing themselves, and the holder of rights (Clark, Kjørholt, \& Moss, 2005; Rinaldi, 2006), rather than as powerless, the holder of a developmentally conditioned inability and needs. Participation starts by listening to children which is constituted as culture and ethics, the way of being and living (Clark, Kjørholt, $\&$ Moss, 2005); it enables participation within which the child's voice is heard, appreciated and included in decisions.

Dialogue is considered an opportunity to establish the so-called pedagogy of listening (Rinaldi, 2005); in the Reggio Emilia concept the dialogical situation enables the learning process as a process of the child's coconstruction of their own knowledge, values and identity (Rinaldi, 2006). Listening is a reciprocal process in which the positions of the listener and the listened to constantly exchange and there are reciprocity of expectations. In a dialogical situation, respectful and encouraging interaction of the preschool teacher with the child is represented (Freire, 1997). The dialogue is the starting point for consultation with the child, which is the foundation for autonomous participation, which requires establishing a serious relation to the child's 
ideas, promotion of the child's self-expression in relation to the adult and promotion of social participation (Matthews, 2003).

The basic assumption of the pedagogy of listening is the understanding of children as intelligent, capable of the construction of knowledge, identity and values. It strives to look for the potential in each child and to give each child a democratic right to be heard and recognised as a citizen in the community (Dahlberg \& Moss, 2006). The characteristic of participation grounded in the pedagogy of listening is the co-involvement of children in decision-making processes in routine everyday activities or in connection to some larger changes at the level of the institution (Kjørholt, 2002), and the local community (Clark, McQuail, \& Moss, 2003).

\section{Researching Child Participation in Slovenian Preschools}

Slovenian pre-school institutions (preschools) are organised as day-care centres and have an enrolment of more than $90 \%$ of the relevant population. Children spend an average of about nine hours per day in institutional care; it is therefore of crucial importance that they are given opportunities for involvement and participation. However, research studies in the 1990s drew attention to a lack of involvement by children in making decisions about themselves in the context of daily routines in preschools. Interviews with the teachers (De Batistič, 1990) identified the existence of prevailing grouporiented daily routines, exercised as collectively organised eating, hygiene and sleeping activities with little attention paid to individual differences (children's needs, desires, biorhythms), as well as to a lack of alternatives/choices available for children. Bahovec and Kodelja (1996) and Dolar Bahovec (2004) pointed to the disciplining nature of everyday routines in preschools, and to a lack of respect for children's rights (especially a right to privacy), although those practices were observed only in a fifth to a quarter of preschools. The study that took place twenty years later (Batistič Zorec, 2010) identified increased diversity in the ways of meeting individual children's needs within daily routines, particularly those concerning the meals or feeding in preschools. In general, children were offered more possibilities to exercise choices and therefore to influence their daily lives in preschools, while poor child participation in the matters concerning sleeping routines remained unchanged.

Promoting child participation has been identified as the most important goal of Slovenian teachers incorporated within their "personal program". In the study on a representative sample (Kroflič et al., 2002) almost two-thirds of preschool teachers claimed that introducing more possibilities for children to co-create and be actively involved in the way they spend their time in preschools would contribute significantly to improving the quality of preschool education. Child participation being placed as the highest priority of Slovenian teachers represented a progressive step away from traditional curricula, and was considerably more supported than by Finnish teachers (Turnšek \& Pekkarinen, 2009). However, the subsequent studies suggest a gap still remains 
between the goals/priorities expressed and what is actually being put into practice.

Examining teachers' practices (Turnšek, 2007; 2008a) revealed that the notion of children's participation is confined mainly to decisions concerning their play or curricula activities, while children are almost entirely excluded from co-creation of their classroom environment. Two fifths of children exert (strong or crucial) influence on the planning of the daily curricula activities; about one fifth are consulted by teachers for their ideas regarding the ways of celebrating important events such as birthdays or mothers' day. The impact of children on decisions typically decreases as decisions become more important. Namely, only up to five per cent of children are consulted on issues such as which toys and materials should be bought or how their classroom should be decorated or organised. Significant differences among preschool settings were also found, reflecting internal institutional cultures (Turnšek, 2008a). After two decades, some improvements on children's influence on bigger decisions have been observed (Batistič Zorec, 2010).

In order to obtain insight into children's perspectives on participation, as well as to promote self-reflection in adults, teachers conducted interviews with the children in their preschool classes (Turnšek, 2009), following the study by Sheridan and Pramling Samuelsson (2001). The differences in the perception of participation between the children and their teachers were brought to light, along with the discrepancy between the expectations of children and the teachers' practices. For many teachers, the meaning of participation was confined to providing the children with alternatives (eg. by asking the children how they would want to spend time outdoors: whether they would like to go for a walk or to play in the preschool playground), whereas for the children, merely choosing between choices provided by the adults was not perceived as "real" participation (Turnšek, 2009).

\section{The Problem and Research Aims}

Based on those research findings, it can be summarized that in most Slovenian preschools, children are at least to some extent involved in the cocreation of their everyday living and learning. There is no doubt that some teachers consult with children (although mostly on "minor" matters), and that they adjust practices according to children's wishes, needs and expectations. However, for the majority of teachers, the concept of child participation is still confined to the concept of providing choices and usually implemented in the context of daily routine activities, while participation is rarely practiced in the form of active learning strategies or citizenship education.

An important incentive for broadening conceptualisations and practices has come about by introducing the three-year training programme based on the Reggio Emilia (RE) pedagogical approach. ${ }^{1}$ The training programme provided

${ }^{1}$ From 2008 to 2011, a training and research project called "The Professional Training of Educators to Include the Elements of the Special Pedagogical Principles of the Reggio Emilia 
preschool teachers with theoretical knowledge as well as with the possibility to practice or experiment the implementation of the main RE concepts and baseline principles. The teachers conducted projects (following the example of progettazione) based on the pedagogy of listening (Rinaldi, 2005) and understanding children as being competent in the processes of co-construction of their own knowledge, values and identity (Rinaldi, 2006), and as actors in the construction and determination of their social life (Prout \& James, 1990) who are able to make decisions at all levels of participation (Hart, 1992). The present study examines whether or to what extent these - postmodern - views of childhood have been adopted by teachers.

The observed inconsistency between the teachers' priorities and their practices as well as the discrepancy between their self-perceptions and the children's expectations (Turnšek, 2007; 2008a; 2009) draws attention to the need for a deepening understanding of the relations between the teachers' cognitions and their behaviour or actions. In order to understand the teachers' (specific) views on promoting child participation in preschools, the associations with their (basic) assumptions and conceptions about children and childhood have to be examined, which reflect the perceived role and status of the child in society and are linked to the understanding of power (Hart, 1992). In this study, we therefore focused on identifying the existence of the teachers' (subjective) "implicit" theories, which have been found to relate significantly to their teaching practices (Turnšek, 2008b). In particular, we are interested in identifying whether the teachers' positions reflect the distinction between the traditional (modern) conception of childhood and the postmodern one (Rutar, 2013). In the final year of RE training, which concluded in 2013, we carried out a survey questionnaire aimed at determining to what extent the teachers agree with the views listed (on the Likert scale) and to examine whether patterns of views can be identified that are statistically significantly linked. The research questions were the following: do the teachers' views form internally consistent patterns; what is the nature of those patterns and what orientations do they reflect.

\section{Methodology}

810 respondents, teachers from all regions of Slovenia who participated in the Reggio Emilia training, were included in the research; the response rate was $93 \%$. Data processing involved the calculation of the mean values and standard deviations. Cluster analysis (Ward's method of Euclidean distance) was used to verify our thesis on the existence of patterns of beliefs.

\section{Results and Discussion}

As may be seen from the Table 1, the average rating of the teachers' agreement with the statements that support the concept of a competent child and child participation ranges from 4 (agree) to 5 (fully agree). The statement

Concept in the Area of Preschool Education" was carried out at the University of Ljubljana. 
saying that the task of adults (in preschools) is to create opportunities for children to express their views, wishes, expectations and ideas on a daily basis (V156) attracts the highest level of agreement; it is also strongly advocated that children should not only be listened to but adults should also seriously take their views into account (V155). The teachers also agree or fully agree that children as merely consumers and they therefore feel they should be involved in shaping their life in preschools to a greater extent (V147); it is not enough for children to be offered choices by the teachers, but it is crucial that children are provided with opportunities to create and implement their own ideas (V166); that preschool children can be active citizens (V 170) who are - even in the period of early childhood period - competent enough to change preschools and significantly contribute to a better life in the community (V 171).

Table 1. Statements on Child Participation - Descriptive Statistics

\begin{tabular}{|c|c|c|c|}
\hline $\begin{array}{l}\text { Variable } \\
\text { Label }\end{array}$ & Statements & Mean & St. dev. \\
\hline V147 & $\begin{array}{l}\text { Preschool children are not only consumers or guests of } \\
\text { preschools and should therefore be involved in shaping } \\
\text { their life in the institution to a greater extent. }\end{array}$ & 4.15 & 0.910 \\
\hline V149 & $\begin{array}{l}\text { Greater participation of children would result in practical } \\
\text { problems because the teachers would not know how to } \\
\text { meet the expectations of all children. }\end{array}$ & 2.58 & 1.169 \\
\hline V150 & $\begin{array}{l}\text { Greater participation would further strengthen the } \\
\text { individualism and orientation of the child only in his/her } \\
\text { own interest. }\end{array}$ & 2.67 & 1.139 \\
\hline V152 & $\begin{array}{l}\text { Children do not have sufficient knowledge and } \\
\text { experience to understand the consequences of their } \\
\text { decisions and take responsibility for them. }\end{array}$ & 2.71 & 1.188 \\
\hline V153 & $\begin{array}{l}\text { For children, childhood should mainly be a period of } \\
\text { playing and a worry-free time, while decisions and } \\
\text { responsibilities need to be taken by adults. }\end{array}$ & 2.40 & 1.187 \\
\hline V155 & $\begin{array}{l}\text { Children have the right not only to have adults listen to } \\
\text { them, but also to take their opinions into account. }\end{array}$ & 4.30 & 0.756 \\
\hline V156 & $\begin{array}{l}\text { The task of adults is that every day we create } \\
\text { opportunities for children to express their views, wishes, } \\
\text { expectations and ideas. }\end{array}$ & 4.38 & 0.746 \\
\hline V158 & $\begin{array}{l}\text { Children should only make decisions concerning their play, } \\
\text { while all other decisions should be made by the teachers. }\end{array}$ & 2.27 & 0.978 \\
\hline V164 & $\begin{array}{l}\text { Children should make decisions and choose from the } \\
\text { options, activities, materials etc. proposed by the teacher } \\
\text { rather than proposing their own. }\end{array}$ & 2.20 & 1.032 \\
\hline V166 & $\begin{array}{l}\text { It is important that children create and implement their } \\
\text { own ideas, not only choose between what adults suggest. }\end{array}$ & 4.19 & 0.821 \\
\hline V169 & $\begin{array}{l}\text { Childhood is a period of immaturity and inability to take } \\
\text { action. }\end{array}$ & 1.71 & 0.927 \\
\hline V170 & $\begin{array}{l}\text { A child can be an active citizen even in the period of } \\
\text { childhood. }\end{array}$ & 4.12 & 0.908 \\
\hline V171 & $\begin{array}{l}\text { Even as early as preschool age, a child is able to change } \\
\text { the preschool and significantly contribute to a better life } \\
\text { in the community. }\end{array}$ & 3.92 & 0.967 \\
\hline
\end{tabular}

Source: Author's estimation. 
Accordingly, the level of agreement with the set of statements contesting the concepts of a competent child and child participation is significantly lower. First, the teachers do not agree that the children would be unable to make a decision. They disagree with the statements that childhood should mostly be a period of playing and a worry-free time, while the decision and responsibilities need to be taken by adults (V153), and with the statement that the children should only make decisions concerning their play, while all other decisions should be made by the teachers (V158). Accordingly, they do not agree that children should only choose from the options, activities, materials etc. "offered" by the teacher, rather than proposing their own (V164). For those claims, the mean estimates are closer to 2 (disagree) than to 3 (partly agree). The statement that childhood is a period of immaturity and inability to take action (V169) attracts the lowest level of agreement.

However, the data also indicate the teachers' concerns with the implications of children's increased participation. The teachers question whether the children have sufficient knowledge and experience to understand the consequences of their decisions, and if they are able to take responsibility for them (V152). Further, they are afraid that increased child participation would cause a practical dilemma concerning how to meet the expectations of all children (V149). At the same time, the data indicate that increased participation could strengthen the individualism and orientation of a child only in his/her own interest (V150). In these three statements, the teachers' mean estimations are closer to 3 (partly agree) than to 2 (disagree).

The cluster analysis (Figure 1) reveals a clear division into two sets of intra-group characteristics which reflect the two opposing patterns of beliefs. On the left side of the tree diagram one finds those teachers' positions that reflect a key assumption according to which (early) childhood is seen as a period of life characterised by immaturity and inability to take action. The closest to this assumption is the belief that children do not have sufficient competencies to assume responsibility for their decisions. Therefore, the chief task of teachers is to ensure that children experience the early years in preschools as a playful period free of responsibilities; children should only decide about their play activities, and from among the choices and opportunities that are proposed by their teachers. These beliefs are on the next level associated with the concern that participation is difficult to implement since it increases the expression of individual interests by children in preschool groups which are hard to satisfy. 
Figure 1. Tree Diagram - Cluster Analysis Results

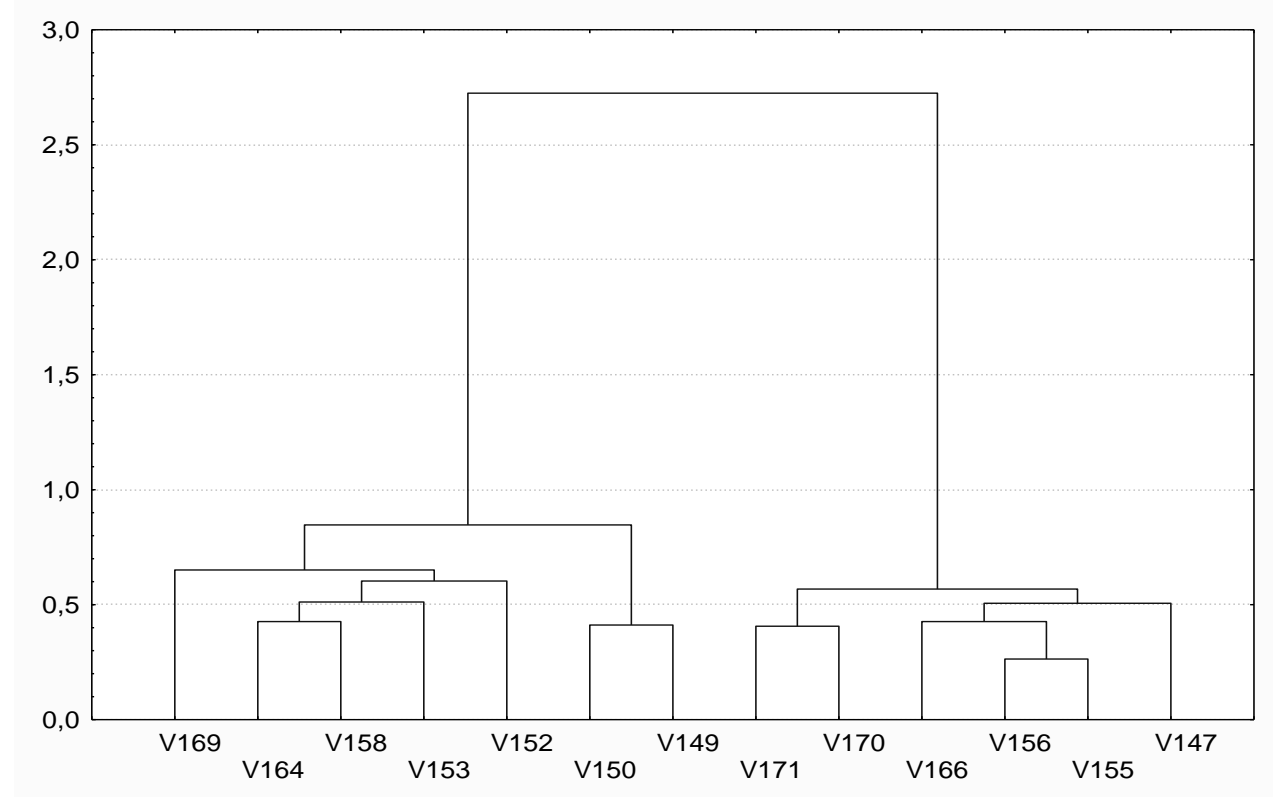

Source: Author's estimation

The teachers' positions placed on the right side of the diagram represent the opposite orientation present in one third of the teachers. Those attitudes and beliefs reflect the belief that children are competent human beings who are able to make significant contributions to their institutions as well as their wider surroundings. The teachers believe that they themselves are responsible for listening to children, and taking their views seriously, as well as for providing an opportunity for children to influence learning and everyday life in preschool. This orientation supports the notion that children need to be in a position to create their own ideas and solutions.

\section{Conclusion}

The study has confirmed our assumption that the teachers' views reflect a contrast between the postmodern and the modern conceptions of childhood and child participation (Rutar, 2013). As they consist of clusters of views that are significantly associated with each other and therefore form the distinctive interpretations of reality, we can regard them as the teachers' implicit theories reflecting their orientations. As had been assumed, the views on practicing child participation in preschools are essentially related to basic assumptions and conceptions of children and childhood.

After the three year intensive course on the Reggio Emilia pedagogical concept, the postmodern orientation became prevalent among the teachers. It represents an internally coherent pattern of views: teachers who perceive children as competent, support autonomous participation (Matthews, 2003), which involves children's direct contribution in the upbringing process (Rutar, 
2013) rather than participation in the form of exercising choices (Turnšek, 2007; 2008a; 2011). The meaning of child participation is extended with the principles of citizenship education, which promotes exercising the child's democratic right to be heard and recognised within the preschool (Dahlberg \& Moss, 2008a; 2008b), as an actor in the quality of preschool education (Sheridan, 2001), and as a citizen of the community (Dahlberg \& Moss, 2006).

However, the traditional (modern) conceptualisation of childhood and child participation remain present in one third of the teachers; the result corresponds with the anti-democratic orientation that has been identified in a similar share (Turnšek \& Pekkarinen, 2009). Our study thus confirms the scientific knowledge that suggests that implicit theories represent those personal constructs that are deeply-rooted and therefore difficult to change (Turnšek, 2008b). A traditional orientation is characterized by the comprehension of the child's incompetence, lack of experience, and understanding required for decision-making, as well as by perception of children as powerless and in need of protection (Woodhead, 1997). It thus represents common sense rather than informed knowledge and is closer to the social representation of childhood reflecting cultural beliefs systems rather than professional positions acquired through teacher education. Such an image of the child is associated with the phenomenon of the protective exclusion of children from decision-making (James \& Prout, 1997), often being grounded on romanticizing childhood (Lansdown, 2001) as a playful period, free of obligations and is recognised in paternalist discourse (Woodhead, 1997). As was hypothesized, teachers holding this set of views are likely to support participation through a mediator (Rutar, 2013) or participation confined to taking choices (provided by others) rather than making (one's own) choices (Turnšek, 2007; 2008a; 2011). This position to a greater extent reflects the liberal concept of the right to free choice rather than the right to be involved in reciprocal and dialogical relationships with adults.

The findings on implicit theories explain - to a certain extent - the discrepancy between the teachers' priorities and their practices (Kroflič, et al., 2002; Turnšek, 2007; 2008a) indicating that child participation is highly valued by a majority of teachers but is not practiced accordingly. Namely, for a certain share of those teachers, the traditional image of the child represents tacit knowledge, which often unreflectively shapes their behaviour and actions, even when being sincerely convinced that it is of vital importance to provide opportunities for children to participate. Their basic assumptions about children not being mature enough or capable of being active in shaping and determining their own social life, represents a significant barrier to the realization of the ethics of participation as an internal culture of being and living in preschools.

\section{References}

Bahovec, Z, \& Kodelja, Z. (1996). Vrtci za današnji čas [Preschools for the present time]. Ljubljana: Center za kulturološke raziskave pri Pedagoškem inštitutu.

Batistič Zorec, M. (2010). Participacija otrok v slovenskih vrtcih z vidika stališč in 
izkušenj vzgojiteljev [Participation of children in the Slovenian preschools in the light of views and experience of educators]. In T. Devjak, M. Batistič Zorec, J. Vogrinc, D. Skubic \& S. Berčnik (Eds.), Pedagoški koncept Reggio Emilia in Kurikulum za vrtce: podobnosti v različnosti. Ljubljana: Pedagoška fakulteta.

Bredekamp, S., \& Rosegrant, T. (1993). Reaching potentials: appropriate curriculum and assessment for young children. Volume 1. Washington D.C.: National Association for the Education of Young Children.

Bredekamp, S. (1996). Developmentally appropriate practice in early childhood programs serving children from birth through age 8. Washington D.C.: National Association for the Education of Young Children.

Clark, A., McQuail, S., \& Moss, P. (2003). Exploring the field of listening to and consulting with young children. Nottingham: Department for Education and Skills.

Clark, A., Kjørholt, A. T., \& Moss, P. (2005). Beyond listening: Children's perspectives on early childhood services. Bristol: The Policy Press, University of Bristol.

Dahlberg, G., \& Moss, P. (2006). Introduction: our Reggio Emilia. In C. Rinaldi (Ed.), In dialogue with Reggio Emilia. London, New York: Routledge.

Dahlberg, G., \& Moss, P. (2008a). Beyond quality in early childhood education and care- languages of evaluation. CESifo DICE Report, 6(2), 21-26. doi:10.4324/9780203966150.

Dahlberg, G., \& Moss, P. (2008b). Ethics and politics in early childhood education. London, New York: Routledge Falmer.

De Batistič, M. (1990). Vpliv institucionalne predšolske vzgoje na socialno emocionalni razvoj otroka: otrokove razvojne potrebe in ravnanje vzgojiteljev [Influence of preschool education on the socio-emotional development of children: children's developmental needs and teachers' practices]. Ljubljana: Filozofska fakulteta.

Dewey, J. (1938). Experience and education. New York: The Macmillan Company.

Dolar Bahovec, E. (2004). Spremembe v naših vrtcih in šolah: tu in zdaj! [Changes in our preschools and schools: here and now!]. In E. Dolar Bahovec \& K. Bregar Golobič, Šola in vrtec skozi ogledalo. Ljubljana: DZS.

Freire, P. (1997). Pedagogy of the oppressed. New York: Continuum.

Hart, A. R. (1992). Children's participation: from tokenism to citizenship. Florence, Italy: UNICEF International Child Development Centre, Spedale degli Innocenti.

James, A., \& Prout, A. (Eds.). (1997). Constructing and reconstructing childhood. Second edition. London: Falmer Press.

Kirby, P., Lanyon, C., Cronin, K., \& Sinclair R. (2003). Building a culture of participation: involving young people in policy, service planning, delivery and evaluation. Retrieved from: bit.ly/1ZhJyqz.

Kjørholt, A. T. (2002). Small is Powerful: discourses on children and participation in Norway. Childhood, 9(1), 63-82.

Kroflič, B., Batistič Zorec, M., Cemič, A., Plestenjak, M., Turnšek, N., \& Vilič, I. (2002). Stališča vzgojiteljic in vzgojiteljev predšolskih otrok do otroštva in vzgoje $v$ vrtcih [Preschool teachers' viewpoints toward childhood and education in preschools]. Ljubljana: Pedagoška fakulteta.

Lansdown, G. (2000). Challenging discrimination. Retrieved from bit.ly/1N4bVS0.

Lansdown, G. (2001). Promoting children's participation in democratic decisionmaking. UNICEF. Florence, Italy: United Nations Children's Fund, Innocenti Research Centre. 
Malaguzzi, L. (1993). History, ideas and basic philosophy. In C. Edwards, L. Gandini, $\&$ G. Forman (Eds.), The hundred languages of children. Norwood, NJ: Ablex.

Matthews, H. (2003). Children and regeneration: setting and agenda for community participation and integration. Children and Society, 17, 264-276.

Prout, A., \& James, A. (1990). A new paradigm for the sociology of childhood? In A. James \& A. Prout (Eds.), Constructiong and reconstructing childhood: contemporary issues in the sociological study of childhood. Basingstoke, Bristol: Falmer Press.

Rinaldi, C. (2005). Documentation and assessment: what is the relationship? In A. Clark, A. T. Kjørholt \& P. Moss (Eds.), Beyond listening: Children's perspectives on early childhood services (pp. 17-29). Bristol: The Policy Press.

Rinaldi, C. (2006). In dialogue with Reggio Emilia: listening, researching and learning. London, New York: Routledge.

Rutar, S. (2013). Poti do participacije otrok v vzgoji [Pathways to children's participation in early childhood education]. Koper: Univerza na Primorskem, Znanstveno-raziskovalno središče, Univerzitetna založba Annales.

Sheridan, S. (2001). Quality evaluation and quality enhancement in preschool: A model of competence development. Early Development and Care, 166, 7-27.

Sheridan, S., \& Pramling Samuelsson, I. (2001). Children's conceptions of participation and influence in pre-school: A perspective on pedagogical quality. Contemporary Issues in Early Childhood, 2(2),169-194.

Turnšek, N. (2007). Children's participation in decision-making in Slovene kindergartens. In A. Ross (Ed.), Citizenship Education in Society: Proceedings of the $9^{\text {th }}$ Conference of the Children's Identity and Citizenship in Europe (pp. 147158). London: Children's Identity and Citizenship in Europe, CiCe.

Turnšek, N. (2008a). Factors determining children's decision-making in Slovene preschools. Odgojne Znanosti, 10(16), 23-38.

Turnšek, N. (2008b). Subjektivne teorije o otroštvu in vzgoji [Subjective theories on childhood and education]. Ljubljana: Pedagoška fakulteta v Ljubljani.

Turnšek, N. (2009). Children as citizens "here and now" - democratic participation as a core citizenship education in early years. 007 International Magazine for Educational Sciences and Practice, 5-6, 1-26.

Turnšek, N. (2011). "Vztrajnost" tradicionalne konstrukcije otroštva v implicitnih in znanstvenih teorijah ["Perseverance" of traditional construction of childhood in implicit and scientific theories]. In T. Devjak \& M. Batistič Zorec (Eds.), Pristop Reggio Emilia - izziv za slovenske vrtce. Ljubljana: Pedagoška fakulteta.

Turnšek, N., \& Pekkarinen, A. (2009). Democratisation of early childhood education in the attitudes of Slovene and Finnish teachers. European Early Childhood Education Research Journal, 17(1), 23-42.

Woodhead, M. (1997). Psychology and the Cultural Construction of Children's Needs. In A. James \& A. Prout (Eds.), Constructing and Reconstructing Childhood. London, New York: RoutledgeFalmer, Taylor \& Francis Group. 